\title{
ON THE WEAPONS USED BY SARMATIANS IN CLOSE COMBATS
}

\author{
Vladislav I. Mamontov \\ Volgograd State Socio-Pedagogical University, Volgograd, Russian Federation
}

\begin{abstract}
The Sarmatians used swords, bows and arrows, spears, darts in combats. A rider dropped from a horse, or a simple warrior, could protect themselves from the enemy by a fighting knife, ax, mace or a battle-flail. These weapons are discovered in the burials of Sarmatian soldiers. The paper describes the similar finds from the Volga-Don region.

The Sarmatians could use every-day items as weapons in the combats. The combat knife (more than $15 \mathrm{~cm}$ in lenght) was tied with a leather cord to the right arm of the warrior. This item was found in the burial mound Verbovsky I, mound 5, burial 1. The findings also include a dagger $(22 \mathrm{~cm}$ ), two combat knives (more than $35 \mathrm{~cm}$ in length), a small wooden shield covered with leather, an ax on a long wooden handle, a heavy tip of "scrap" (the burial mound Pervomaisky VII, mound 40, burial 5), a wedge-shaped ax (the burial mound Verbovsky I, mound 5, burial 1), an iron ax (the burial mound Pervomaisky VII, mound 9, burial 3), an iron hook with a bushing (the burial mound Ilyevka, mound 12, burial 1). The military burials of the Sarmatians in the Volga-Don interfluve contained separate items of weapons that could be used in close combats: a stone mace-battle-flail with a hole in the center of the ball, a long iron rod- battle-flail with a ring on a narrow side. The leather belt was threaded through a hole or a ring, held in the hand for swinging and striking with a heavy object.

The findings of melee weapons in the burials of the Sarmatians confirm the views of researchers that the the Sarmatian warriors were represented by both riders who used specific ranged weapons, and foot soldiers - the prototype of a future well-armed infantry.

Key words: Sarmatian warrior, melee weapons, combat knife, dagger, celt, stone mace, battle-flail, hook.

Citation. Mamontov V.I. On the Weapons Used by Sarmatians in Close Combats. Vestnik Volgogradskogo gosudarstvennogo universiteta. Seriya 4, Istoriya. Regionovedenie. Mezhdunarodnye otnosheniya [Science Journal of Volgograd State University. History. Area Studies. International Relations], 2018, vol. 23, no. 3, pp. 153-158. (in Russian). DOI: https://doi.org/10.15688/jvolsu4.2018.3.13
\end{abstract}

УДК 930.26

Дата поступления статьи: 20.03.2018

ББК 63.48

Дата принятия статьи: 10.04.2018

\section{К ВОПРОСУ ОБ ОРУЖИИ БЛИЖНЕГО БОЯ САРМАТОВ}

\author{
Владислав Иванович Мамонтов \\ Волгоградский государственный социально-педагогический университет, \\ г. Волгоград, Российская Федерация
}

\footnotetext{
Аннотация. Сарматы использовали в бою меч, лук и стрелы, копье, дротик. Всадник, сброшенный с лошади, или простой воин могли защититься от врага боевым ножом, топором, булавой или кистенем. Это $\infty$ оружие ближнего боя встречается в погребениях сарматских воинов. В статье приводится описание подоб용 ных находок, обнаруженных в Волго-Донском регионе.

В бою сарматы могли применить как оружие вещи, которым они пользовались в быту. Это - топорсекира на длинной деревянной рукояти, тяжелый наконечник «лома», клиновидный топор, железная пешнятопор, железный крюк с втулкой.

В воинских погребениях сарматов междуречья Волги и Дона встречены единичные предметы вооружения, которые могли использовать в ближнем бою: каменная булава-кистень с отверстием в центре шара, длинный железный стержень-кистень с кольцом на узкой стороне. Кожаный ремень продевался через отвер-

() стие или кольцо, удерживался в руке для замаха и удара тяжелым предметом.
} 
Находки в погребениях сарматов оружия ближнего боя подтверждают взгляды исследователей, что наряду со всадниками со специфическим оружием дальнего боя в воинской среде сарматов появляются подразделения пеших воинов - прообраз будущей хорошо вооруженной пехоты.

Ключевые слова: воин-сармат, оружие ближнего боя, боевой нож, кинжал, кельт, каменная булава, кистень, крюк.

Цитирование. Мамонтов В. И. К вопросу об оружии ближнего боя сарматов // Вестник Волгоградского государственного университета. Серия 4, История. Регионоведение. Международные отношения. - 2018. T. 23, № 3. - C. 153-158. - DOI: https://doi.org/10.15688/jvolsu4.2018.3.13

Воины-сарматы имели стандартный набор вооружения: лук и колчан, меч, кинжал, копье или дротик. Но материалы раскопок показали, что сарматы, наряду с этими, широко распространенными видами вооружения имели предметы, которые могли использоваться как оружие ближнего боя.

В первую очередь боевые ножи, которые носили в чехлах на поясе, подвязывали шнуром к ноге или засовывали за край обуви, голенище сапога. Такой боевой нож много позднее получил название «засапожный». Клинок в данном случае всегда находился под рукой всадника: им могли бросить в спину противника, перерезать петлю аркана на шее, снять узду с убитой лошади, а в случае рукопашной схватки, защитить себя. Такой нож отличался от хозяйственных ножей своими размерами. Бытовые ножи сарматов имеют в среднем длину 8-10 см. Длина боевых ножей из сарматских погребений доходит до 22 и более сантиметров.

В могильнике Первомайском VII найдены фрагменты «засапожных» ножей. Они имеют короткие черенки со следами волокон от деревянных рукоятей. Так, длина ножа из погребения 3 в кургане 14 была 15,1 см (рис. 1, 8), длина тяжелого клинка - 14,2 см (рис.1, 9). Он найден у правой ноги воина, к которой был подвязан, вместе с гарнитурой ременных украшений: небольшого круглого диска из створки раковины, двух серебряных колец, ракушки каури, костяной трубчатой пронизи, серебряной прямоугольной пластинки - наконечника ремешка [2, с. 108]. В кургане 59 этого же могильника рядом с железными наконечниками стрел лежал боевой нож с широким клинком (рис. 1, 10). Он, без учета утерянной части, имел длину $13 \mathrm{~cm}$.

Кинжал со следами волокон дерева на черенке рукояти и бронзовой пластинкой на перекрестье (рис. 1, 4) обнаружен в сарматском погребении в кургане 5 Вербовского мо- гильника. Длина - 37,2 см. Там же найден однолезвийный нож длиной 15 см (рис. 1, 7) и короткий кинжал (длина 22 см), на край ножен которого надета крестовидная бронзовая обойма. Деревянные накладки на рукояти стягивались бронзовой обоймой навершия с круглым диском наверху (рис. 1, 3). Ножны были обтянуты тонкой кожей ярко-красного цвета.

В могильнике Усть-Погожье (курган 2, погребение 3) обнаружены фрагменты крупного ножа с широким клинком и с упором у основания рукояти (рис. 1,11 ). Когда-то нож имел длинное лезвие (средняя часть его рассыпалась). Длина сохранившихся частей ножа $9,5 \mathrm{~cm}$.

Интересен материал погребения 1 (кенотафа) из кургана 2 могильника Котлубань V $[1$, c. 15]. В северо-восточном углу квадратной ямы обнаружен набор серебряных украшений ремней узды (бусы, ажурные фалары, мелкие бляхи и т. д.). В противоположном углу - бронзовое ситечко с позолотой и фрагменты деревянного предмета с кусками обшивки из толстой кожи. Это был, полагаем, овальный щит с размерами $55 \times 35$ см, положенный внешней поверхностью на землю. Сверху на нем лежали два железных однолезвийных ножа (рис. $1,1,2$ ). Клинки хранились в деревянных ножнах. Они имеют плавный изгиб спинки и длинные черешки рукояти, обложенные деревянными пластинами. Внешне они идентичны. Длина большого клинка 39,5 см, ширина лезвия 2 см. Длина меньшего ножа 35,8 см.

В курганном могильнике Петропавловка I (курган 3, погребение 1) найдены фрагменты ножа длиной 22,5 см. Он находился в деревянных ножнах с круговой железной обкладкой входного отверстия (рис. 1, б).

Иногда сарматских воинов сопровождают железные топоры и пешни, которые применялись в хозяйстве кочевника. При необхо- 
димости они могли использоваться и в ближнем бою. Массивная секира (длина $15 \mathrm{~cm}$ ) лежала рядом с воином в погребении 5 из кургана 40 могильника Первомайский VII (рис. 2, 5). Надетая на топорище, она являлась ударным оружием в ближней схватке. Клиновидный боевой топор (длина 20,6 см) встречен в погребении из кургана 5 могильника Вербовский I (рис. 2, 1). Рядом положено массивное острие, похожее на острие лома (рис. 2, 4). Это тяжелое железное орудие длиной 22,3 cм, внутрь которого для прочности заковали крупную прямоугольную бронзовую пластину. Втулка имеет глубокую конусовидную полость для насаживания на древко. Орудием можно было производить земляные работы, но оно могло быть использовано и как колющее или ударное оружие в ближней схватке.

Железные пешни, считают, применялись при рытье углубления для землянки на зимнике или ямы для тела погребенного на племенном кладбище, для обтесывания дерева при условии поперечного расположения клинка относительно рукояти (средневековые топоры Востока). Но это было в первую очередь оружие ближнего боя (как бронзовые кельты в эпоху поздней бронзы). Пешни встречены в курганах могильника Первомайский VII (курган 9, погребение $3,-$ рис. 1,12 ; курган 46, погребение $6,-$ рис. 2,3$)$.

Любопытно изделие из кургана 2 (могильник Усть-Погожье). В яме найдена круглая полированная булава из серого плотного песчаника (рис. 1, 13). Размеры: 7,2 × 8,2 см. В центре массивного изделия высверлено округлое отверстие. Вряд ли этот предмет был символом власти, как жезл или скипетр. Это ударное оружие. Диаметр деревянного стержня небольшой (диаметры 1,7 и 1,9 см). Тонкая деревянная рукоять не выдержала бы сильного удара по доспехам противника. По- лагаем, что через отверстие в шаре продевалась и крепилась кожаная лента, удерживаемая в руке воина. Воин мог делать широкие замахи для ударов таким каменным «кистенем». Изделие датируется концом IV началом III в. до н. э. [3, с. 164].

В кургане 4 могильника Вербовский II обнаружены фрагменты железного предмета в виде длинного тяжелого стержня с закругленными концами (длина 28,4 см), к одному из которых крепилось железное кольцо (рис. 1, 5). Через него ударное оружие (кистень ?) подвязывалось кожаной лентой к деревянной рукояти или, как вариант, петля ленты крепко зажималась в кулаке.

В кургане 12 Ильевского курганного могильника встречен фрагмент железного крюка (длина 19 см) с втулкой для насаживания на древко (рис. 2, 2).Такие крюки, считают, использовались в быту для вынимания кусков мяса из кипящего котла. Но крюк мог иметь и военное назначение. Во время боевых схваток им можно было зацепить и свалить врага с лошади, выбить оружие из рук противника.

Исследователи военных походов и стычек сарматов, их оружия и полевой тактики с применением тяжелой и легкой кавалерии иногда упоминают и пеших воинов, вооруженных оружием ближнего боя. На древних авторов, в этой связи, ссылается А.М. Хазанов в своих исследованиях по военному делу сарматов $[4$, c. 53,$54 ; 5$, с. 87], считая, что именно они «выработали тактику ближнего боя» [4, с. 56]. К сожалению, авторами публикаций не всегда указывается на широкое применение в рукопашных схватках оружия ближнего боя малых форм, таких как боевые ножи, пешни, крюки, кистени и т. д. Задача статьи только на примере находок из материалов одной экспедиции указать на этот пробел. 


\section{ПРИЛОЖЕНИЯ}

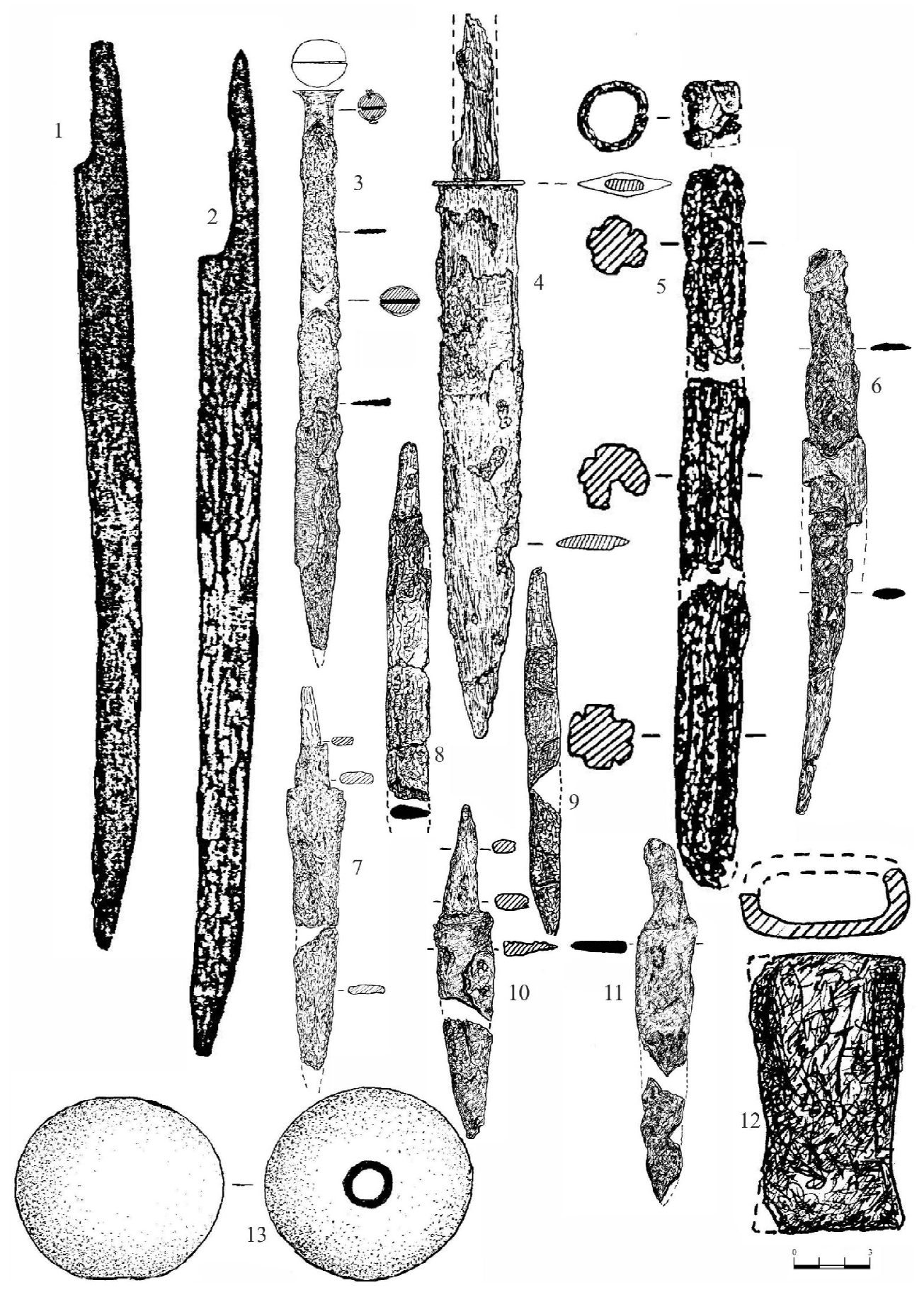

Рис. 1. Находки оружия в воинских погребениях сарматов междуречья Волги и Дона:

1, 2 - Котлубань V, курган 2, погребение 1; 3, 4, 7 - Вербовский I, курган 5, погребение 1;

5 - Первомайский VII, курган 4, погребение $1 ; 6$ - Петропавловский I, курган 3 , погребение 1 ;

8,9 - Первомайский VII, курган 14 , погребение $3 ; 10$ - Первомайский VII, курган 59 , погребение 1 ;

11,13 - Усть-Погожье, курган 2, погребение 3; 12 - Первомайский VII, курган 9, погребение 3

Fig. 1. Weapons in the Sarmatian military burials in the Volga-Don interfluve:

1, 2 - Kotluban V, burial mound 2, burial 1; 3, 4, 7 - Verbovsky I, burial mound 5, burial 1;

5 - Pervomaisky VII, burial mound 4, burial 1; 6 - Petropavlovsk I, burial mound 3, burial 1;

8, 9 - Pervomaisky VII, burial mound 14, burial 3; 10 - Pervomaysky VII, burial 59, burial 1;

11,13 - Ust-Pogozhye, burial mound 2, burial 3; 12 - Pervomaisky VII, burial mound 9, burial 3 


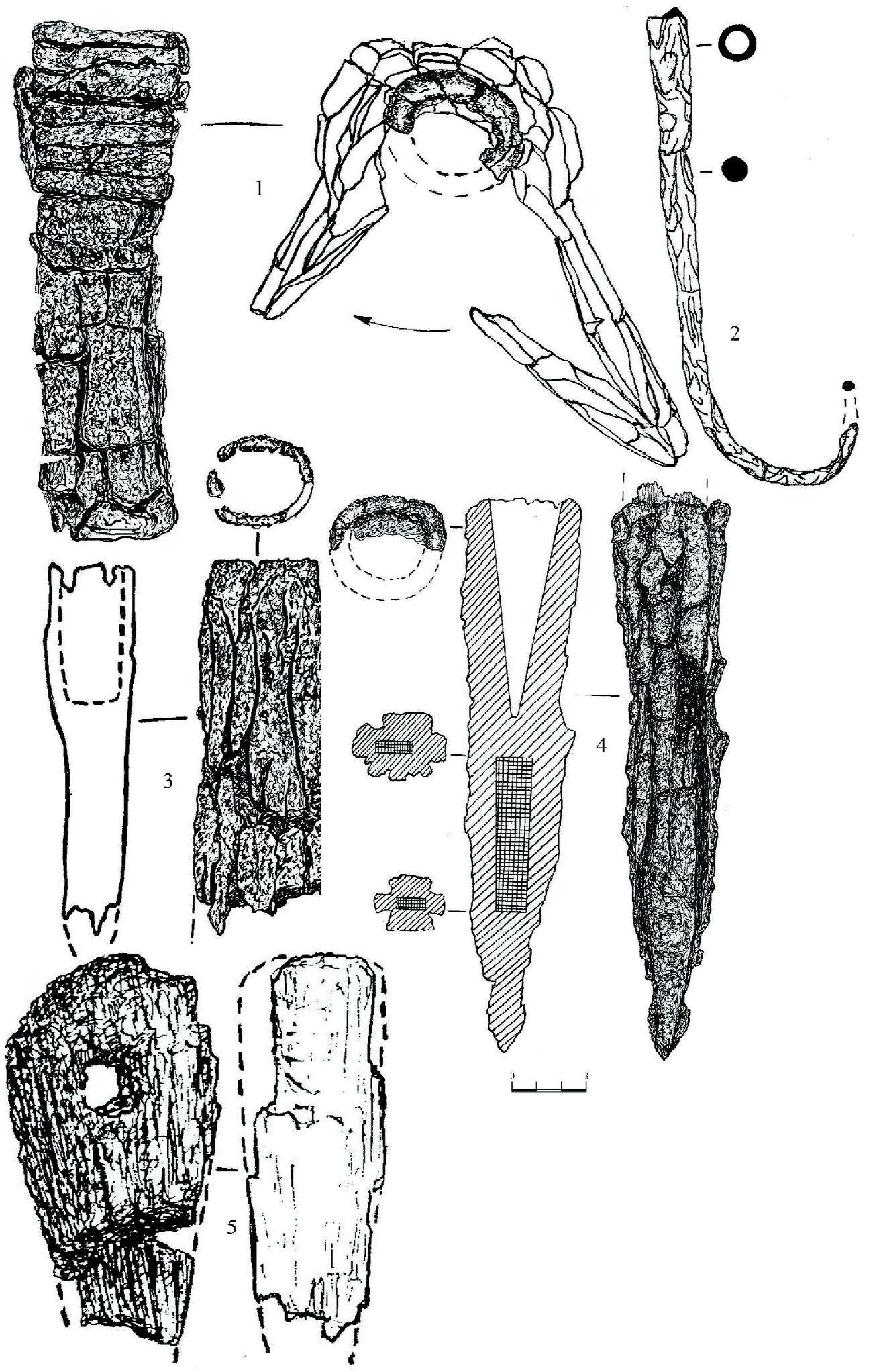

Рис. 2. Находки из воинских погребений сарматов междуречья Волги и Дона:

1, 4 - Вербовский I, курган 5, погребение 1; 2 - Ильевка, курган 12, погребение 1;

3 - Первомайский VII, курган 46, погребение 6; 5 - Первомайский VII, курган 40, погребение 5

Fig. 2. Finds from the military burials of Sarmatians in the Volga-Don interfluves:

1, 4 - Verbovsky I, burial mound 5, burial 1; 2 - Ilyovka, burial mound 12, burial 1;

3 - Pervomaisky VII, burial mound 46, burial 6; 5 - Pervomaisky VII, burial mound 40, burial 5 


\section{РАННИЙ ЖЕЛЕЗНЫЙ ВЕК \\ СПИСОК ЛИТЕРАТУРЫ}

1. Лисицын, И. П. Отчет Городищенского отряда Волго-Донской археологической экспедиции ЛОИА АН СССР в 1973 г. / И. П. Лисицын // Архив ВОКМ. - 1973. - № 124. - 27 c.

2. Мамонтов, В. И. Древнее население левобережья Дона (по материалам курганного могильника Первомайский VII) / В. И. Мамонтов. - Волгоград : Изд-во ВолГУ, 2000. - 192 с.

3. Сергацков, И. В. О времени заселения сарматами северной части Волго-Донского междуречья / И. В. Сергацков // Советская археология. 1992. - № 1. - С. 162-174.

4. Хазанов, А. М. Характерные черты сарматского военного искусства / А. М. Хазанов // Советская археология. - 1970. - № 2. - С. 52-63.

5. Хазанов, А. М. Очерки военного дела сарматов / А. М. Хазанов. - М. : Наука, 1971. - 171 с.

\section{REFERENCES}

1. Lisitsyn I.P. Otchet Gorodishchenskogo otryada Volgo-Donskoy arkheologicheskoy ekspeditsii LOIA AN SSSR v 1973 g. [Report of the Gorodishchensky Detachment of the Volga-Don Archaeological Expedition in 1973, AS USSR]. Arkhiv VOKM [Archives of the VOKM], 1973, no. 124.27 p.

2. Mamontov V.I. Drevnee naselenie levoberezhya Dona (po materialam kurgannogo mogilnika Pervomayskiy VII) [The Ancient Population of the Left Bank of the Don River (Based on the Materials of the Burial Mound Pervomaisky VII]. Volgograd, Izd-vo VolGU, 2000. 192 p.

3. Sergatskov I.V. O vremeni zaseleniya sarmatami severnoy chasti Volgo-Donskogo mezhdurechya [The Chronology of the Sarmatians' Settlement in the Northern Part of the Volga-Don Interfluve]. Sovetskaya arkheologiya [Soviet Archaeology], 1992, no. 1, pp. 162-174.

4. Khazanov A.M. Kharakternye cherty sarmatskogo voennogo iskusstva [The Characteristics of Sarmatian Military Art]. Sovetskaya arkheologiya, 1970, no. 2, pp. 52-63.

5. Khazanov A.M. Ocherki voennogo dela sarmatov [Essays on the Military Affairs of the Sarmatians]. Moscow, Nauka Publ., 1971. 171 p.

\section{Information About the Author}

Vladislav I. Mamontov, Candidate of Sciences (History), Associate Professor, Professor of Department of History of Russia and Local-History Education, Head of Scientific and Industrial Laboratory of Archaeology and Restoration, Volgograd State Socio-Pedagogical University, Prosp. Lenina, 27, 400066 Volgograd, Russian Federation, legenda@vspu.ru, https://orcid.org/0000-0002-4661-8194

\section{Информация об авторе}

Владислав Иванович Мамонтов, кандидат исторических наук, доцент, профессор кафедры отечественной истории и историко-краеведческого образования, заведующий научно-производственной лабораторией археологии и реставрации, Волгоградский государственный социально-педагогический университет, просп. им. В.И. Ленина, 27, 400066 г. Волгоград, Российская Федерация, legenda@vspu.ru, https://orcid.org/0000-0002-4661-8194 